\title{
Keberkesanan Permainan Persuasif Grafik Terhadap Perubahan Sikap Pemilihan Makanan Sihat Dalam Kalangan Murid-murid Tahun Dua
}

\author{
Norlia Mat Esa ${ }^{a}$, Ramlah Mailok ${ }^{b}$, Maizatul Hayati Mohamad Yatim \\ aEducational Technology Department, Teachers Education Institute Ipoh Campus, 31150 Hulu Kinta, Perak, Malaysia \\ ${ }^{b}$ Faculty of Art, Computing \& Creative Industry, UPSI, 35900, Tanjong Malim, Perak, Malaysia
}

*Corresponding author: norliamatesa@ipgm.edu.my

\begin{abstract}
This study aims to determine the effectiveness of persuasive graphic game as compared to game without persuasive graphic on the attitude change on selection of healthy foods among year two students. This study is a quasi-experimental with pre and post test for the non-equivalent group. The study sample comprised of 62 students consisting of 32 students in treatment group and 30 students in the control group. Analysing the data set using Analysis of Covariance (ANCOVA), the results indicate that the adjusted mean $(79.90)$ of the persuasive graphic game is statistically significantly higher $(\mathrm{F}(1,57)=$ $16.63, \mathrm{p}<.001)$ than the adjusted mean $(73.70)$ of the non-persuasive graphic game. The obtained effect size $(\mathrm{ES}=+0.83$ ), which is equivalent to approximately four fifth of a standard deviation, denotes the educational significance, favouring the persuasive graphic game group.
\end{abstract}

Keywords: Persuasive technology; persuasive game; graphic; attitude; healthy diet

Abstrak

Kajian ini bertujuan untuk mengkaji keberkesanan permainan persuasif grafik berbanding dengan permainan tanpa persuasif grafik terhadap perubahan sikap pemilihan makanan sihat dalam kalangan murid-murid tahun dua. Kajian ini berbentuk kuasi-eksperimen dengan ujian pra dan pasca bagi kumpulan tidak seimbang. Sampel kajian ini adalah seramai 62 orang murid yang terdiri daripada 32 murid kumpulan rawatan dan 30 murid kumpulan kawalan. Penganalisisan data dengan kaedah analisis kovarian (ANCOVA) menunjukkan bahawa min terlaras (79.90) bagi kumpulan rawatan adalah lebih tinggi dan signifikan secara statistik $(\mathrm{F}(1,57)=16.63, \mathrm{p}<.001)$ berbanding dengan min terlaras $(73.70)$ kumpulan kawalan. Perbezaan min terlaras ini, yang memihak kepada kumpulan permainan persuasif, adalah juga signifikan secara pendidikan (educationally significant) berdasarkan pengiraan kesan saiz (effect size) bernilai 0.83 yang bersamaan dengan empat per lima sisihan piawai.

Kata kunci: Teknologi Persuasif; permainan persuasif; grafik; sikap; pemakanan sihat

(C) 2017 Penerbit UTM Press. All rights reserved

\subsection{PENGENALAN}

Dalam bidang pendidikan, teknologi persuasif boleh digunakan di dalam pengajaran dan pembelajaran kerana ia melibatkan proses mengasimilasikan pengetahuan baru dengan niat untuk menukar idea seseorang serta mengubah sikap atau kedua-duanya tanpa menggunakan paksaan atau penipuan (Fogg, 2003). Teknologi persuasif di dalam permainan boleh menawarkan sesuatu yang baru dan berguna untuk bilik darjah dan guru-guru (Joseph \& Morten, 2012), kerana matlamat utama permainan persuasif tidak hanya mendidik atau meningkatkan senaman fizikal, tetapi bertujuan untuk memujuk pengguna untuk mengubah suai tingkah laku mereka (Orji, Mandryk, Vassileva \& Gerling, 2013; Mintz \& Aagaard, 2012).

Sesuai dengan kemajuan sains dan teknologi maka permainan komputer tidak dapat dipisahkan daripada kanak-kanak. Permainan komputer telah pun diterima dalam kalangan kanak-kanak dan remaja (Zorbaz, Ulas \& Kizildag, 2015; Apostol, Zaharescu \& Alexe, 2013). Ini disokong oleh kaji selidik kebangsaan yang dijalankan oleh National Institute on Media and the Family (2001), 92\% daripada kanak-kanak dan remaja berusia 2-17 tahun bermain permainan komputer. Menggunakan kelebihan permainan komputer dalam kalangan murid-murid ini secara tidak langsung permainan komputer ini dapat dijadikan medium bagi membantu memujuk murid-murid untuk mengubah sikap.

Dalam konteks permainan persuasif, grafik bertindak sebagai elemen persuasif yang digambarkan sebagai maklum balas kepada sesuatu tindakan dan mampu mempengaruhi tindak balas atau tingkah laku pemain (Hera, 2014). Di antara penggunaan persuasif grafik dalam permainan komputer adalah dalam bentuk pengukuhan positif iaitu ganjaran (Yoganathan \& Kajanan, 2014; Zuckerman \& Gal-Oz, 2014). Ganjaran yang dipamerkan di dalam permainan komputer menawarkan ganjaran berbentuk maya seperti mesej pujian melalui grafik (Zuckerman \& Gal-Oz, 2014).

Isu dalam mendidik murid-murid terhadap pemakanan sihat perlu diberi perhatian. Berdasarkan satu kaji selidik terhadap muridmurid sekolah rendah di Semenanjung Malaysia dan Malaysia Timur, didapati 12.6\% murid-murid adalah berat badan berlebihan dan 
13.5\% adalah obesiti (Wan Abdul Manan, Wan Muda, Norazawati \& Lee, 2012). Berdasarkan dapatan yang dibekalkan oleh pakar nutrisi Jabatan Kesihatan Negeri Perak, mengesahkan bahawa Negeri Perak menduduki tempat ke-lima dari 16 buah negeri termasuk tiga wilayah persekutuan dalam peratusan murid tahun enam yang mempunyai masalah obesiti pada tahun 2011 iaitu sebanyak $10.5 \%$ dan meningkat kepada tempat ke-empat pada tahun 2012 iaitu sebanyak $10.9 \%$.

Oleh itu kajian ini diperlukan bagi mengkaji kesan permainan persuasif grafik oleh murid kumpulan rawatan dengan permainan tanpa persuasif grafik oleh murid dalam kumpulan kawalan terhadap perubahan sikap mereka dalam pemilihan pemakanan sihat.

\subsection{KAJIAN LITERATUR}

\section{Teknologi Persuasif}

Teknologi Persuasif bertujuan untuk membawa perubahan yang diingini dengan membentuk dan mengukuhkan tingkah laku atau sikap mengenai sesuatu isu, tindakan, atau objek (Mifsud, 2013; Fogg, 2003). Teknologi persuasif menjanjikan pendekatan yang amat meyakinkan dalam memujuk individu ke arah gaya hidup yang lebih sihat seperti penggunaan teknologi sebagai alat dalam pemantauan tahap gula dalam darah, media seperti dalam kesan simulasi atau sebagai ejen sosial dalam memberi ganjaran positif terhadap sesuatu tingkah laku (Fogg, 2003).

Keberkesanan teknologi persuasif telah terbukti, sebagai contoh untuk menyokong pengguna dalam aktiviti fizikal (Gouveia \& Karapanos, 2013), mengekalkan diet yang sihat (Brindal et al., 2013), berhenti merokok (Paay et al., 2014), mengurangkan berat badan (Fritz, Huang, Murphy \& Zimmermann, 2014) atau menjimatkan tenaga (Reeves, Cummings, Scarborough \& Yeykelis, 2013). Keputusan empirik juga telah menunjukkan bahawa teknologi persuasif boleh mengubah sikap dan tingkah laku pengguna kepada tahap yang lebih baik (Matthews, Win, Oinas-Kukkonen \& Freeman, 2016; Kaptein \& Van Halteren, 2013; Baranowski et al., 2013).

Fogg (2003) telah memperkenalkan Traid Fungsi yang mengandungi tujuh prinsip persuasif yang biasa digunakan di dalam alat teknologi persuasif ialah pengurangan (reduction), tunnelling, penyesuaian (tailoring), cadangan, pemantauan diri, pengawasan, dan syarat (conditioning). Prinsip yang diguna pakai dalam permainan persuasif grafik bagi kajian ini adalah prinsip syarat.

Prinsip syarat ditonjolkan dengan menggunakan pelaziman operan (operant conditioning) bagi memperkukuhkan tingkah laku sasaran. Pelaziman operan biasanya berbentuk pengukuhan positif seperti ganjaran atau pujian. Kerap digunakan di dalam permainan komputer melalui bunyi atau bantuan grafik (Yoganathan \& Kajanan, 2014). Permainan komputer boleh menjadi contoh yang paling baik bagi teknologi menggunakan pelaziman operan dengan memberi ganjaran kepada pemain dalam bentuk peningkatan skor permainan.

\section{Permainan Persuasif}

Kajian telah menunjukkan bahawa permainan komputer kini merupakan sebahagian rutin biasa zaman kanak-kanak dan remaja (contoh, Ruggiero, 2015; Ferguson \& Olson, 2013; Adachi \& Willoughby, 2013; Ventura, Shute \& Zhao, 2013). Kajian oleh Scholastic (2012), mendapati jumlah masa yang dihabiskan bermain permainan komputer berbeza-beza mengikut umur. Secara purata, kanak-kanak berusia 8 hingga 13 tahun menghabiskan masa 32 minit sehari, dan kanak-kanak 14 hingga 18 tahun pula menghabiskan 20 minit sehari bermain permainan video.

Permainan persuasif telah terbukti menjadi alat yang berkesan untuk menggalakkan kehidupan sihat dengan cara menyelitkan atau melaksanakan perubahan tingkah laku dalam bentuk yang dikehendaki (Khaled \& Ingram, 2012; Orji, Vassileva \& Mandryk, 2012). Antara kesannya ialah perubahan sikap terhadap orang kelainan upaya (Gerling et al., 2014), mengurangkan berat badan (Staiano, Abraham \& Calvert, 2013), dan pemakanan sihat (Baranowski, \& Frankel, 2012).

Matlamat utama permainan persuasif, tidak untuk mendidik atau untuk meningkatkan latihan fizikal, tetapi untuk memujuk pengguna untuk mengubah tingkah laku mereka. Berbeza dengan kebanyakan permainan komputer yang lain lebih menitikberatkan peraturan, pertandingan, matlamat dan objektif, interaksi, hasil dan maklum balas dan perwakilan atau cerita tanpa memikirkan perubahan sikap pemain (Thompson, 2012).

Niat untuk memujuk adalah penting dalam permainan persuasif walau tidak ditunjukkan dengan jelas kerana pembangun permainan berniat untuk mempengaruhi tingkah laku pemain permainan mereka. Permainan persuasif mampu menyebabkan kesan persuasif semasa bermain apabila permainan tersebut dibina berasaskan mekanisme prosedur retorik, keasyikan, penglibatan dan aliran (Bogost, 2007).

i) Prosedur Retorik

Bogost (2007) mentakrifkan istilah prosedur retorik sebagai "kuasa unik persuasif" permainan komputer dan cara mereka membentuk persuasif dan mempengaruhi pemain. Prosedur retorik merujuk kepada kuasa sistem untuk membuat elemen-elemen permainan itu persuasif. Bogost (2007) menamakan prosedur retorik sebagai seni pujukan melalui perwakilan berasaskan peraturan dan interaksi dan bukan perkataan yang dituturkan, menulis, imej atau gambar bergerak. Kenyataan Bogost ini merujuk kepada keupayaan permainan persuasif untuk mengubah kepercayaan dan sikap pemain dengan membentuk imej mental dalam pemikiran pemain.

ii) Keasyikan (Immersion)

Menurut Kim dan Shute (2015), salah satu cara elemen dipersembahkan dalam permainan adalah dengan mewujudkan perasaan keasyikan (immersion). Keasyikan boleh ditakrifkan sebagai perasaan asyik yang dikelilingi oleh suasana realiti. Dalam konteks permainan komputer perasaan asyik ini ditakrifkan sebagai proses mental yang terlibat dalam permainan iaitu merasakan diri sebahagian dari permainan. Menurut Ruggiero (2014), apabila pemain yang aktif terlibat dalam permainan mereka juga akan mengamalkan sikap yang digalakkan di dalam permainan tersebut. 


\section{iii) Aliran}

Aliran dalam permainan adalah untuk mencari keseimbangan antara menyediakan cabaran permainan dan keupayaan pemain. Menurut Buttussi et al., (2013), kebiasaannya konsep permainan adalah tidak berterus-terang dan pemain sendiri tidak mengetahui apa yang diharapkan dan apa matlamat terakhir mereka. Kiili (2005) menambah, matlamat sering ditakrifkan oleh pereka permainan dan bukannya oleh pemain. Ronimus, Kujala, Tolvanen dan Lyytinen (2014), merumuskan tiga syarat asas bagi mewujudkan aliran di dalam permainan komputer:

i) Permainan ini memberi ganjaran intrinsik dan menggalakkan pemain secara sukarela berhasrat untuk bermain permainan.

ii) Permainan ini menawarkan jumlah cabaran yang sepadan dengan keupayaan pemain.

iii) Pemain perlu berasa mempunyai kawalan ke atas aktiviti permainan.

iv) Penglibatan (Engagement)

Penglibatan adalah apabila pemain mendapati permainan itu sangat mengasyikkan dan tanpa mereka sedari, mereka telah mengasimilasikan nilai-nilai dan fakta-fakta yang diperolehi di dalam dunia permainan (Quinn, 2005). Menurut Bogost (2007) permainan tidak seperti media lain dalam kuasa mereka untuk memujuk kerana permainan bukan sahaja menyampaikan mesej, tetapi juga meniru pengalaman. Pandangan ini turut disokong oleh Green dan Donahue (2009), iaitu tahap di mana seseorang individu itu menyerap cerita atau terbawa-bawa ke dalam dunia naratif, maka cerita itu boleh mempengaruhi kepercayaan pemain terhadap dunia sebenar. Ringkasnya, permainan yang baik perlu mempertimbangkan penglibatan pemain di dalam permainan, di samping mengandungi kandungan pelajaran yang sesuai untuk perkara yang diajar (Egenfeldt-Nielsen, 2015).

Kesimpulan yang boleh dibuat dari kajian literatur ini adalah prosedur retorik, keasyikan, aliran dan penglibatan merupakan sebahagian daripada permainan dan mekanisme ini boleh memujuk, mengubah suai atau menukar nilai-nilai, kehendak, kepercayaan dan tindakan pemain. Semua ini berlaku apabila pemain diserap ke dalam dunia permainan maka permain akan menyerap semua nilai-nilai dan logik.

Grafik

Menurut Azagba dan Sharaf (2013), grafik dikatakan mempunyai kuasa pujukan yang lebih tinggi kerana gambaran emosi yang wujud dalam persembahan grafik seperti maklumat yang lebih jelas daripada teks dan grafik lebih mudah untuk dimanipulasikan berbanding teks. Jika dilihat dari konteks penerimaan persuasif grafik dalam kalangan kanak-kanak, didapati sekitar usia lapan tahun (zaman pertengahan kanak-kanak), majoriti kanak-kanak telah dapat memahami niat sesuatu persuasif grafik (Connel, Brucks \& Nielsen, 2014). Ini adalah kerana pada peringkat usia ini kanak-kanak cenderung untuk mengingati maklumat-maklumat yang disampaikan dengan bantuan grafik berbanding teks (Fingeret, 2012).

Kuasa persuasif grafik terletak pada keupayaan persembahan grafik untuk memberi makna atau berkongsi makna grafik tersebut dengan permainan persuasif (Kjeldsen, 2012). Keadaan ini boleh berlaku apabila mesej persuasif itu dapat memberi rasa kewujudan kepada pemain seolah-olah diri mereka sebahagian daripada permainan, memberi situasi yang sama seperti situasi sebenar, maklumat yang ingin disampaikan dapat difahami dengan segera dan pemain dapat menyerap dan menerima segala fakta yang diperolehi dalam permainan (Kjeldsen, 2012).

Bagi kajian ini, murid yang terlibat adalah murid-murid sekolah rendah yang berumur lapan tahun maka penggunaan grafik sesuai digunakan. Ini adalah kerana pada peringkat usia ini murid-murid cenderung untuk mengingati maklumat-maklumat yang disampaikan dengan bantuan grafik berbanding teks (Fingeret, 2012). Grafik dikatakan berkesan sebagai mesej persuasif dalam bidang pengiklanan (Sussenbach, 2013; Owens, Chaparro \& Palmer, 2011). Namun kurang kajian yang menyokong penggunaan grafik dalam permainan persuasif (Bertel, 2011). Bersandarkan kemampuan grafik ini maka penyelidik memilih grafik sebagai persuasif untuk prinsip syarat. Pemilihan prinsip persuasif dan grafik di dalam kajian ditunjukkan dalam Jadual 1.

Jadual 1 Implikasi mekanisme permainan dan fungsi grafik

\begin{tabular}{|c|c|c|}
\hline $\begin{array}{l}\text { Mekanisme } \\
\text { permainan }\end{array}$ & Huraian & Fungsi Grafik \\
\hline Prosedur retorik & $\begin{array}{l}\text { - Kuasa atau keupayaan elemen- } \\
\text { elemen permainan memujuk } \\
\text { pemain untuk mengubah sikap dan } \\
\text { kepercayaa. }\end{array}$ & $\begin{array}{l}\text { - Grafik dengan prinsip syarat } \\
\text { dipersembahkan kepada murid. }\end{array}$ \\
\hline $\begin{array}{l}\text { Keasyikan } \\
\text { (immersion) }\end{array}$ & $\begin{array}{l}\text { - Pemain merasakan diri mereka } \\
\text { sebahagian daripada permainan. } \\
\text { - Situasi yang dipersembahkan } \\
\text { dalam permainan adalah sama } \\
\text { seperti situasi sebenar (realiti). }\end{array}$ & $\begin{array}{l}\text { - Memaparkan peringkat } \\
\text { yang kelihatuan seperti } \\
\text { sebenar iaituasi situasi di kantin } \\
\text { sekolah, di luar pagar sekolah dan } \\
\text { di pasar malam. }\end{array}$ \\
\hline Aliran & $\begin{array}{l}\text { - Tahap kesukaran permainan adalah } \\
\text { berperingkat daripada mudah } \\
\text { kepada sukar. } \\
\text { - Ganjaran disediakan. }\end{array}$ & $\begin{array}{l}\text { - Menggunakan pelaziman operan } \\
\text { berbentuk pengukuhan positif, } \\
\text { iaitu ganjaran untuk melaksanakan } \\
\text { sasaran tingkah laku. } \\
\text { - Tahap permainan yang berbeza }\end{array}$ \\
\hline
\end{tabular}




\begin{tabular}{|c|c|c|}
\hline $\begin{array}{l}\text { Mekanisme } \\
\text { permainan }\end{array}$ & Huraian & Fungsi Grafik \\
\hline & & $\begin{array}{l}\text { daripada mudah kepada sukar. } \\
\text { - Grafik dengan pelaziman operan } \\
\text { mampu membuatkan kanak-kanak } \\
\text { lebih terbuka kepada pujukan } \\
\text { untuk mengubah sikap (Organ, } \\
\text { Proverbs \& Squires, 2013). }\end{array}$ \\
\hline
\end{tabular}

\begin{tabular}{ll}
\hline Penglibatan & Apabila pemain menyerap atau \\
& mengasimilasikan segala fakta \\
& yang diperolehi dalam permainan \\
& maka ini dapat mempengaruhi \\
& pemain dalam kehidupan sebenar.
\end{tabular}

Sebahagian besar penyelidikan psikologi berkaitan kesan permainan terhadap sikap murid-murid lebih memberi tumpuan kepada kesan negatif yang berpotensi memberi kerosakan yang berkaitan dengan keganasan, ketagihan dan kemurungan seperti kajian-kajian yang telah dijalankan oleh Ferguson (2013), Lemola et al. (2011) dan Anderson et al. (2010). Bagi memahami kesan permainan komputer terhadap sikap murid-murid, perspektif yang lebih seimbang adalah diperlukan. Kajian yang dijalankan perlulah mempertimbangkan bukan sahaja kesan negatif tetapi manfaat bermain permainan komputer tersebut.

Sikap

Penggunaan alat sebagai medium perantara seperti filem, surat khabar dan permainan adalah lebih berkesan untuk mewujudkan perubahan sikap (Bohner \& Dickel, 2011). Permainan komputer merupakan satu alat yang cemerlang kerana berjaya mengajar pemain tentang sikap yang perlu bagi sesuatu tingkah laku yang berjaya (Anderson, Gentile \& Dill, 2012). Setiap orang yang bermain permainan komputer menunjukkan perhatian yang lebih baik kepada isyarat visual berbanding orang yang tidak bermain permainan komputer (Kim et al., 2015).

Kebanyakan kajian yang telah dijalankan menunjukkan bahawa permainan digital, iaitu, permainan yang dimainkan di dalam komputer atau talian, adalah berkesan untuk mengubah sikap pengguna (Hasan, 2013). Ini memberi ruang kepada penggunaan permainan sebagai alat yang persuasif membantu pemain untuk menukar sikap dengan membekalkan mereka dengan pengetahuan yang berkesan dalam permainan mereka.

Pemakanan Sihat

Menurut Aguayo, Gayatri dan Nina (2014) adalah penting untuk mengajar tabiat pemakanan sihat kepada kanak-kanak di awal kehidupan mereka. Ibu bapa amat mempengaruhi pilihan makanan kanak-kanak ketika di rumah tetapi tiada bimbingan ketika kanak-kanak ini berada di sekolah (Gibson, 2012). Ini disokong oleh Dudley, Cotton dan Peralta (2015), oleh kerana kanak-kanak banyak menghabiskan sejumlah besar masa mereka dalam persekitaran pendidikan, maka sekolah telah dikenal pasti sebagai tempat utama bagi pelaksanaan program pendidikan pemakanan sihat. Menurut Fahmida et al. (2015), ibu bapa kepada kanak-kanak sekolah yang mengalami masalah obesiti melaporkan bahawa pendekatan tradisional kepada pengurusan obesiti sedia ada adalah tidak membantu. Oleh itu terdapat keperluan untuk membangunkan satu pendekatan yang sesuai untuk membantu kanak-kanak dalam soal pemilihan makanan sihat dan memastikan ibu bapa dan guru-guru berkemahiran untuk menyokong (Webb \& Morancie, 2015).

Dalam usaha untuk menggalakkan tabiat pemakanan yang sihat, dan seterusnya mengurangkan kadar obesiti, pengetahuan tentang makanan dan pemakanan dipercayai menjadi keutamaan (Nguyen, de Villiers, Fourie, Bourne \& Hendricks, 2015). Oleh itu adalah penting pemakanan yang sihat dimulakan di peringkat kanak-kanak supaya mereka boleh memulakan satu pelan pemakanan sihat secepat mungkin.

Bagi menangani masalah-masalah yang telah dikemukakan ini, maka kajian bagi mengkaji kesan penggunaan permainan persuasif grafik bagi mengubah sikap murid-murid terhadap pemakanan sihat perlu dilaksanakan. Lebih spesifik lagi, kajian ini bertujuan untuk menjawab soalan kajian dan untuk menguji hipotesis berikut:

Soalan kajian: Apakah kesan permainan persuasif grafik berbanding dengan permainan tanpa persuasif grafik terhadap perubahan sikap memilih makanan sihat dalam kalangan murid-murid tahun dua?

Hipotesis $\mathrm{Nol}\left(\mathrm{H}_{0}\right)$ : Tidak ada perbezaan yang signifikan secara statistik dalam perubahan sikap memilih makanan sihat murid-murid tahun dua yang bermain permainan persuasif grafik berbanding perubahan sikap murid-murid tahun dua yang bermain permainan tanpa persuasif grafik.

\subsection{METODOLOGI}

\section{Reka Bentuk Kajian dan Persampelan}

Kajian ini menggunakan reka bentuk kajian eksperimen kuasi yang berdasarkan ujian pra-pasca bagi kumpulan-kumpulan tidak seimbang (Campbell \& Stanley, 1966). Ini membolehkan penyelidik untuk mengukur samada pembelajaran permainan ini dipertingkatkan atau tidak dengan membandingkan sikap sebelum dan selepas permainan terhadap kumpulan yang sama (Mills \& Gay, 2015). Reka bentuk 
eksperimen kuasi digunakan kerana terdapat pelbagai pemboleh ubah bebas yang tidak dapat dimanipulasikan, seperti jantina, bangsa, umur, tahap IQ, tahap pendidikan, latar belakang keluarga dan sebagainya (Chua, 2011). Reka bentuk ini menggunakan kelas-kelas yang sedia ada (intact group), iaitu subjek kajian bagi Kumpulan Rawatan dan Kawalan tidak boleh dipilih secara rawak kerana terikat dengan peraturan yang telah ditetapkan oleh pihak sekolah (Chua 2011; Wiersma 2000; Johnson \& Christensen, 2000). Kumpulan rawatan (A) terdiri daripada 32 orang murid. Manakala kumpulan kawalan (B) terdiri daripada 30 orang murid. Kedua-dua kumpulan ini perlu menduduki ujian pra dan ujian pasca dan ditadbir oleh guru mata pelajaran sains bagi kedua-dua kumpulan. Setelah menduduki ujian pra, murid-murid kumpulan rawatan akan bermain permainan persuasif grafik dan murid-murid kumpulan kawalan akan bermain permainan tanpa persuasif grafik. Selesai permainan semua murid akan menduduki ujian pasca.

\section{Populasi dan Sampel Kajian}

Sampel bagi kajian ini tidak dipilih secara rawak. Penyelidik telah menggunakan pasangan bagi dua kelas yang mempunyai keputusan yang hampir sama dalam mata pelajaran sains bagi ujian selaras satu daripada empat kelas tahun dua seperti ditunjukkan dalam Jadual 2.

Jadual 2 Min skor mata pelajaran sains bagi ujian selaras satu

\begin{tabular}{cc}
\hline Kelas & Min \\
\hline 2 Hikmah & 45.06 \\
2 Harapan & 43.91 \\
\hline
\end{tabular}

\section{Instrumen}

Penyelidik menilai perubahan sikap murid-murid terhadap pemakanan sihat menggunakan soal selidik yang dibina sendiri berasaskan Teori Tingkah Laku Terancang (Ajzen, 2005). Ujian pra dan pasca sikap mengandungi 15 soalan. Untuk menguji sikap kanak-kanak dalam kajian ini, kaedah Smileyometer digunakan menggantikan skala tradisional Likert. Skala Smileyometer dikatakan salah satu petunjuk yang paling sesuai untuk digunakan apabila sampel kajian adalah kanak-kanak (Read \& MacFarlane, 2006; Maizatul Hayati, 2009). Oleh kerana kanak-kanak berfikir dan bertindak balas kepada situasi berbeza daripada orang dewasa maka kaedah soal selidik yang mesra kanak-kanak diperlukan untuk membuat mereka berasa selesa (Preece, Rogers \& Sharp, 2007). Instrumen yang mengandungi Skala Likert 4-mata dipilih bagi kajian ini kerana penggunaan titik tengah menyukarkan responden kajian dalam kalangan kanak-kank untuk mentafsir maksud titik tengah (Kyriakides, Demetriou \& Charalambous, 2006).

Bagi menguji kesahan soalan-soalan yang digunakan, analisis kandungan oleh pakar telah dilakukan. Pemilihan dua panel pakar dilakukan berdasarkan kepakaran dan pengalaman yang mendalam dalam bidang pedagogi kanak-kanak bagi mendapatkan komen dan cadangan bagi laras bahasa yang sesuai dan difahami oleh murid-murid tahun dua. Bagi menguji kesahan item rumus Corrected Item Total Correlation telah digunakan. Item dengan nilai koefision kesahan di bawah 0.3 telah diperbaiki dan nilai item yang lebih besar atau sama dengan 0.3, item tersebut kekal digunakan untuk pelaksanaan penelitian (Surtiyono, 2004).

Bagi memastikan setiap item yang digubal dalam ujian pra dan pasca mempunyai ciri-ciri kesahan dan kebolehpercayaan, analisis dibuat dan keputusan yang diperolehi bagi pekali kebolehpercayaan ketekalan dalaman instrumen soal selidik ujian pra sikap ialah 0.71 menunjukkan kebolehpercayaan bagi ujian ini adalah tinggi (Pallant, 2011; Fraenkel \& Walen, 1996). Pallant (2011) berpendapat nilai indeks alfa sebanyak 0.7 atau ke atas adalah baik bagi skala instrumen yang mempunyai sepuluh atau lebih item. Oleh kerana soal selidik ini mempunyai 15 item, nilai kebolehpercayaan bagi pemboleh ubah dianggap baik.

\section{Prosedur Penganalisisan Data}

Analisis Kovarian (ANCOVA) digunakan untuk menganalisis data ujian pasca dengan mengambil ujian pra sebagai kovariat. Penggunaan ANCOVA, mengikut Borg dan Gall (1989), boleh menangani masalah perbezaan sedia ada di antara kumpulan kerana ANCOVA dapat mengurangkan kesan perbezaan sedia ada dengan membuat pelarasan terhadap min ujian pasca bagi kedua-dua kumpulan rawatan dan kawalan. Keputusan utama dari analisis kovarian ialah nisbah $\mathrm{F}$ dan nilai kebarangkalian untuk kesan utama kumpulan. Paras kesignifikan yang digunakan untuk menguji hipotesis kajian ini ditentukan pada paras .05. Namun demikian, sebelum dianalisis dengan menggunakan ANCOVA, data-data ujian pra dan ujian pasca diperiksa bagi memastikan ianya bersifat normal dan memenuhi anggapan homogeneity-ofslopes. Di samping ANCOVA, kesan saiz juga diukur bagi melaporkan kekuatan hubungan antara pemboleh ubah bersandar dan pemboleh ubah tidak bersandar.

\subsection{DAPATAN}

Pemeriksaan taburan-taburan data ujian pra dan data ujian pasca menunjukkan bahawa nilai-nilai kurtosis dan skewness untuk kedua-dua taburan tersebut berada dalam julat di antara -1 dan +1 (Tabachnich \& Fidell, 2007). Lantas, taburan-taburan ujian pra dan ujian pasca adalah bersifat normal dan sesuai untuk dianalisis secara parametrik. Di samping itu, interaksi di antara kumpulan dan kovariat (ujian pra) adalah tidak signifikan $(\mathrm{F}=.001, \mathrm{p}=.97>.05)$, dan keadaan ini membawa maksud bahawa min ujian pra adalah sama merentas kumpulan eksperimen dan kawalan. Ketidaksignifikanan dalam interaksi kumpulan dan kovariat bermakna anggapan kehomogenan kecuraman (homogeneity of slopes) dipenuhi, dan seterusnya, analisis kovarian (ANCOVA) boleh digunakan tanpa was-was. 
Jadual 3 Keputusan ANCOVA bagi pasca ujian berdasarkan kumpulan

Analisis Kovarian

\begin{tabular}{cccccc}
\hline Sumber & $\begin{array}{c}\text { Jumlah } \\
\text { Kuasadua }\end{array}$ & df & $\begin{array}{c}\text { Kuasadua } \\
\text { Min }\end{array}$ & F & p \\
\hline Group & 582.83 & 1 & 582.83 & 16.63 & .000 \\
Pre & 2625.54 & 1 & 2625.54 & 74.21 & .000 \\
Error & 1997.80 & 57 & 35.05 & & \\
\hline
\end{tabular}

Min

\begin{tabular}{|c|c|c|c|c|c|c|c|}
\hline \multirow{2}{*}{ Kumpulan } & \multirow{2}{*}{$\mathrm{N}$} & \multicolumn{2}{|c|}{ Kovariat } & \multicolumn{2}{|c|}{ Ujian pasca } & \multirow{2}{*}{$\begin{array}{c}\text { Min } \\
\text { terlaras }\end{array}$} & \multirow{2}{*}{$\begin{array}{c}\text { Kesan } \\
\text { saiz }\end{array}$} \\
\hline & & Min & SD & Min & SD & & \\
\hline Rawatan & 32 & 66.50 & 9.11 & 79.33 & 10.15 & 79.96 & 0.83 \\
\hline Kawalan & 30 & 68.17 & 8.66 & 74.33 & 7.51 & 73.70 & \\
\hline Jumlah & 62 & & & & & & \\
\hline
\end{tabular}

Berdasarkan Jadual 3, keputusan ANCOVA menunjukkan bahawa skor sikap murid-murid tahun dua yang mengikuti permainan persuasif grafik adalah lebih tinggi dan signifikan secara statistik $(F=16.63, p<.001)$ berbanding dengan skor sikap murid-murid yang bermain dengan permainan tanpa persuasif grfik. Oleh itu, hipotesis kajian diterima. Di samping itu, memandangkan kesan saiz dengan angka sebanyak 0.83 yang bersamaan dengan empat per lima sisihan piawai, maka boleh dihujah bahawa perbezaan yang memihak kepada kumpulan murid-murid yang mengikuti permainan persuasif grafik adalah juga signifikan secara amalan. Kesan saiz sebanyak 0.83 menunjukkan bahawa min terlaras kumpulan eksperimen berada pada persentil ke-78 dalam taburan kumpulan kawalan. Ini menunjukkan bahawa pelajar pertengahan (yakni, persentil ke-50) dalam kumpulan rawatan yang telah bermain permainan persuasif grafik berjaya mencapai pada persentil ke-78 dalam agihan linear taburan pencapaian kumpulan kawalan.

\subsection{PERBINCANGAN}

Berdasarkan keputusan ANCOVA $(\mathrm{F}=16.63, \mathrm{p}<.001)$ dan hasil pengiraan kesan saiz $(\mathrm{ES}=0.83)$, maka boleh disimpulkan bahawa hipotesis kajian ini adalah diterima. Tafsirannya ialah skor sikap untuk murid-murid tahun dua yang terlibat di dalam permainan persuasif grafik adalah lebih tinggi dan signifikan secara statistik jika dibandingkan dengan skor sikap murid-murid yang terlibat dalam permainan tanpa persuasif grafik.

Grafik yang digunakan kepada prinsip syarat berjaya memberi kuasa pujukan yang lebih tinggi kerana gambaran maklumat yang lebih jelas dan mudah difahami (Connors, 2012). Prinsip syarat dalam bentuk ganjaran seperti mata permainan dapat memberi prestasi yang baik kepada pemain untuk permainan yang seterusnya. Ternyata bahawa kuasa persuasif grafik adalah terletak pada keupayaan persembahan grafik. Kemampuan grafik untuk memberi makna atau berkongsi makna grafik tersebut dengan permainan persuasif adalah tepat sekali. Penemuan ini juga menyokong dapatan kajian Owen et al., (2012) bahawa sistem ganjaran berpotensi untuk meningkatkan pilihan makanan sihat dalam kalangan kanak-kanak sekali gus mengesahkan dapatan bahawa permainan persuasif grafik boleh dijadikan contoh terbaik bagi menggunakan "operant conditioning" (Fogg, 2003).

Situasi permainan yang dipersembahkan dalam bentuk tiga fasa permainan iaitu situasi kantin sekolah, di luar pagar sekolah dan di pasar malam berjaya mewujudkan perasaan keasyikan kepada pemain. Ini kerana pemain tidak hanya melibatkan diri dalam permainan tetapi mereka juga terlibat secara aktif dan mengambil bahagian dalam pembinaan pengalaman Ruggiero (2014). Apabila sesuatu permainan itu berjaya melibatkan emosi atau pun perasaan terhadap sesuatu maka secara tidak langsung permainan itu berjaya memujuk pemain untuk bergerak balas. Seterusnya apabila pemain itu menyerap cerita dan terbawa-bawa ke dalam dunia naratif, maka cerita itu boleh mempengaruhi kepercayaan pemain terhadap dunia sebenar.

Justeru, pendekatan permainan dengan prinsip persuasif grafik sesuai diterima pakai di sekolah rendah terutama sebagai sokongan kepada mata pelajaran sains, selain bertindak sebagai permainan pendidikan serta boleh dijadikan alternatif kepada guru dalam mempelbagaikan pendekatan pengajaran.

Perlu ditegaskan di sini bahawa limitasi kajian ini adalah penggunaan sampel yang kecil dan jangka masa intervensi yang pendek yang hanya mengambil dua sesi pengajaran dan pembelajaran serta melibatkan satu topik sahaja dalam sukatan pelajaran sains tahun dua iaitu "Keperluan Asas Kita \& Makanan dan Khasiatnya". Oleh itu, perwakilan (representativeness) daripada dapatan kajian ini adalah terbatas. Justeru itu, sebarang implikasi daripada dapatan kajian yang diusulkan di sini perlulah diterima secara berwaspada.

\subsection{KESIMPULAN}

Bagi implikasi untuk kajian-kajian yang akan datang, dicadangkan penggunaan sampel murid-murid yang lebih representatif supaya kesahan untuk generalisasi dapat ditentukan. Di samping itu, kajian-kajian selanjutnya perlu diperluaskan kepada aspek kesesuaian pelaksanaan permainan persuasif yang bukan hanya kepada bidang, mata pelajaran atau topik-topik tertentu sahaja tetapi juga kepada kumpulan sasaran yang lain seperti kesannya kepada kumpulan murid yang telah dikenalpasti mempunyai masalah obesiti atau berat badan berlebihan. Bilangan sampel kajian ini adalah lebih kecil dan terhad kepada murid tahun dua di sekolah kebangsaan. Oleh yang demikian kajian ini wajar diulang dengan bilangan sampel yang lebih besar serta merangkumi jumlah lokasi yang lebih meluas. 
Rujukan

Adachi, P. J., \& Willoughby, T. (2013). More than Just Fun and Games: The Longitudinal Relationships between Strategic Video Games, Self-Reported Problem Solving Skills, And Academic Grades. Journal of Youth and Adolescence, 42, 1041-1052. Doi: 10.1007/s10964-013-9913-9

Aguayo, V. M., Gayatri, S. G., \& Nina, B. (2014). Scoring Child Nutrition in India Measuring the Performance of States, Economic and Political Weekly, Vol. XLIX, 97-103. Diperoleh 3 April, 2015 daripada www.epw.in/special-articles/scoring-child-nutrition-india.html

Ajzen, I. (2005). Attitudes, Personality, And Behavior (2nd Ed.). New York: MacGraw-Hill.

Apostol, S. S., Zaharescu, L. I., \& Alexe, I. L. (2013). Gamification Of Learning And Educational Games. Elearning \& Software for Education, $2,67-72$. http://dx.doi.org/10.12753/2066-026X-13-118

Azagba, S., \& Sharaf, M. F. (2013). The Effect Of Graphic Cigarette Warning Labels On Smoking Behavior: Evidence From The Canadian Experience. Nicotine Tobacco Res 15: 708-717 doi: 10.1136/tc.2005.013177

Baranowski, T., Buday, R., Thompson, D., Lyons, E. J., Lu, A. S., \& Baranowski, J. (2013). Developing Games For Health Behavior Ccange: Getting Started. Games Health J, Aug, 2(4), 183-190.

Baranowski, T., Cullen, K.W., \& Nicklas, T. (2012). Are Current Health Behavioral Change Models Helpful In Guiding Prevention Of Weight Gain Efforts? Obes Res, 11 (Suppl 10), 23S-43S.

Bertel, L. B. (2011). The Use of Rewards in Persuasive Design. Poster Proceedings of the 5th International Conference on Persuasive Technology, Oulu University Press.

Bogost, I. (2007). Persuasive Games: The Expressive Power of Videogames. The MIT Press. Diperoleh 10 Jun, 2012 daripada http://www.hfgkarlsruhe.de/ arafinski/gamestudies/txt/Bogost_PersuasiveGames.pdf

Bohner, G., \& Dickel, N. (2011). Attitudes and Attitude Change. Annual Review of Psychology, 62, 391-417. doi: 10.1146/annurev.psych.121208.131609

Brindal, E., Hendrie, G., Freyne, J., Coombe, M., Berkovsky, S., \& Noakes, M. (2013). Design and Pilot Results of a Mobile Phone Weight-Loss Application for Women Starting a Meal Replacement Programme. Journal of Telemedicine and Telecare, 19(3), 166-174.

Buttussi, F., Pellis, T., Cabas, V. A., Pausler, D., Carchietti, E., \& Chittaro, L. (2013). Evaluation Of A 3D Serious Game For Advanced Life Support Retraining. Int J Med Inform, 2013 Sep, 82(9), 798-809. doi: 10.1016/j.ijmedinf.2013.05.007

Campbell, D. T., \& Stanley, J. C. (1966). Experimental And Quasi-Experimental Designs. New York: Houghton Mifflin Company.

Connel, P. M., Brucks, M., \& Nielsen, J. H. (2014). How Childhood Advertising Exposure Can Create Biased Product Evaluations That Persist into Adulthood. Journal of Consumer Research, 41(1), 119-134. Doi:10.1086/675218

Csikzentmihalyi, M. (1991). Flow: The Psychology of Optimal Experience. Harper Perennial, New York.

Dudley, D. A., Cotton, W. G., \& Peralta, L. R. (2015). Teaching Approaches And Strategies That Promote Healthy Eating In Primary School Children: A Systematic Review And Meta-Analysis. Int J Behav Nutr Phys Activ, 12(28).doi: 10.1186/s12966-015-0182-8

Egenfeldt-Nielsen, S. (2015). Elearn Magazine: What Makes A Good Learning Game? Going Beyond Edutainment. Diperoleh 5 Mac, 2017 daripada http://elearnmag.acm.org/archive.cfm?aid=1943210.

Fahmida, U., Kolopaking R., Santika, O., Sriani, S., Umar, J., Htet, M. K., \& Ferguson, E. (2015). Effectiveness In Improving Knowledge, Practices, And Intakes Of "Key Problem Nutrients" Of A Complementary Feeding Intervention Developed By Using Linear Programming: Experience in Lombok, Indonesia. Am J Clin Nutr, 101(3), 455-6. doi: 10.3945/ajcn.114.087775

Ferguson, C. J., \& Olson, C. K. (2013). Friends, Fun, Frustration And Fantasy: Child Motivations For Video Game Play. Motivation and Emotion, 37, 154-164. doi:1007/s11031-012-9284-7

Fingeret, L. (2012). Graphics in Children's In-Formational Texts: A Content Analysis. (Unpublished doctoral dissertation). Michigan State University, East Lansing.

Fogg, B. J. (2003). Persuasive Technology, Using Computers to Change What People Think and Do. San Francisco: Morgan Kaufman Publishers.

Fraenkel, J. R., \& Wallen, N. E. (1996). How To Design And Evaluate Research In Education. San Francisco: McGraw-Hill.

Fritz, T., Huang, E. M., Murphy, G. C., \& Zimmermann, T. (2014). Persuasive Technology In The Real World: A Study Of Long Term Use Of Activity Sensing Devices For Fitness. In Proceedings of the 32nd annual ACM conference on Human Factors In Computing Systems, 487-496. ACM.

Gerling, K. M., Mandryk, R. L., Birk, M. V., Miller, M., \& Orji, R. (2014). The Effects Of Embodied Persuasive Games On Player Attitudes Toward People Using Wheelchairs. In Proc. CHI '14, ACM (2014), 3413-3422.

Gibson, E. L. (2012). A Narrative Review Of Psychological And Educational Strategies Applied To Young Children's Eating Behaviours Aimed At Reducing Obesity Risk. Obes Rev, 13(1), 85-95. Diperoleh 4 Nov, 2011 daripada http://www.eufic.org/article/en/artid/Parental-influence-children-food-preferences-andenergy-intake/

Gouveia, R. \& Karapanos, E. (2013). Footprint Tracker: Supporting Diary Studies With Lifelogging. In Proceedings of CHI'13, 2921-2930.

Green, M. C., \& Donahue, J. K. (2009). Simulated Worlds: Transportation Into Narratives. Persuasiveness of Narratives. In Markman, K., Klein, W. M., \& Suhr, J. A., (eds.). Handbook of Imagination And Mental Simulation, 241-256. New York: Psychology Press.

Hasan, Y., Laurent, B., Michael, S., \& Brad, J. B. (2013). The More You Play, The More Aggressive You Become: A Long Term Experimental Study of Cumulative Violent Video Game Effects on Hostile Expectations and Aggressive Behavior. Journal of Experimental Social Psychology, 49, $2,224-7$.

Hellstrom, C., Nilsson, K. W., Leppert, J., \& Aslund C. (2012). Influences of Motives To Play And Time Spent Gaming On The Negative Consequences Of Adolescent Online Computer Gaming. Computers in Human Behavior, 28, 1379-1387.

Johnson, B., \& Christensen, L. (2000). Educational Research Quantitative and Qualitative Approaches. Boston: Allyn and Bacon.

Joseph, M., \& Morten, A. (2012). The application of persuasive technology to educational settings. Educational Technology Research and Development. 60(3), 483499. US: Springer.

Kaptein, M. C., \& Van Halteren, A. (2013). Adaptive Persuasive Messaging To Increase Service Retention. J. Personal Ubiquitous Comput, 17(6), 1173-1185.

Khaled, R., \& Ingram, G. (2012). Tales From The Front Lines Of A Large-Scale Serious Game Project. CHI'12, 69-78.

Khaled, R., Barr, P., Biddle, R., Noble, J., \& Fischer, R. (2007). Fine Tuning the Persuasion in Persuasive Games. Proceedings of Persuasive: $2^{\text {nd }}$ Internet Journal Conference on Persuasive Technology, Lecture Notes in Computer Science 4744. Springer, 36-74. Diperoleh April 11, 2012 daripada http://f3.tiera.ru/2/Cs_Computer\%20science/CsLn_Lecture\%20notes/Persuasive\%20Technology,\%202\%20conf.,\%20PERSUASIVE\%202007\%28LNCS4 $744, \% 20$ Springer, $\% 202007 \% 29 \% 28$ ISBN\%209783540770053\%29\%28327s\%29_CsLn_pdf

Kiili, K. (2005). Educational Game Design: Experiential Gaming Model Revised. Tampere University of Technology, Pori. Research Report 4. Diperoleh Ogos 3, 2012 daripada http://amc.pori.tut.fi/publications/EducationalGameDesign.pdf.

Kjeldsen, J. E. (2012). Pictorial Argumentation in Advertising: Visual Tropes and Figures as a Way of Creating Visual Argumentation. New York: Springer.

Kim, Y. J., \& Shute, V. J. (2015). Opportunities and Challenges In Assessing And Supporting Creativity In Video Games. In J. Kaufmann \& G. Green (Eds.), Research Frontiers In Creativity. San Diego, CA: Academic.

Kim, Y. H., Kang, D. W., Kim, D., Kim, H. J., Sasaki, Y., \& Watanabe, T. (2015). Real Time Strategy Video Game Experience And Visual Perceptual Learning. J Neurosci, 35(29):10485-92.

Kyriakides, L., Demetriou, D., \& Charalambous, C. (2006). Generating Criteria For Evaluating Teachers Through Teacher Effectiveness Research. Educational Research, 48(1), 1-20. doi: 0.1080/00131880500498297

Maizatul Hayati Mohamad Yatim. (2009). Children, Computer and Creativity: Usability Guidelines for Designing a Game Authoring Tool for Children. Diperoleh 29 Mac, 2013 daripada http://edoc.bibliothek.unihalle.de/servlets/MCRFileNodeServlet/HALCoRe_derivate_00003870/maizatulyatim.pdf

Matthews, J., Win, K. T., Oinas-Kukkonen, H., Freeman, M. (2016). Persuasive Technology In Mobile Applications Promoting Physical Activity: A Systematic Review. J Med Syst. Mar; 40(3), 72. doi: 10.1007/s10916-015-0425-x.

Mifsud, C. L. (2013). Attitudes Towards And Effects Of The Use Of Video Games In Classroom Learning With Specific Reference To Literacy Attainment. Research in Education, 90, 32-52. http://dx.doi.org/10.7227/RIE.90.1.3 
Mills, G. E., \& Gay, L. R. (2015). Educational Research: Competencies For Analysis And Applications. Pearson.

Mintz, J., \& Aagaard, M. (2012). The Application of Persuasive Technology To Educational Settings. Educational Technology Research and Development, 60(3), 483-499. doi:10.1007/s11423-012-9232-y

Nguyen, K. A., de Villiers, A., Fourie, J. M., Bourne, L. T., \& Hendricks, M. K. (2015). The feasibility of Implementing Food-Based Dietary Guidelines In The South African Primary-School Curriculum. Public Health Nutr, 18(1), 167-75. doi: 10.1017/S1368980013003194

Organ, S., Proverbs, D., \& Squires, G. (2013). Motivations for Energy Efficiency Refurbishment In Owner Occupied Housing. Structural Survey, 31(2), 101-120. doi:10.1108/02630801311317527

Orji, R., Mandryk, R. L., Vassileva, J., \& Gerling, K. M. (2013). Tailoring Persuasive Health Games To Gamer Type. In: Proc. of CHI 2013 , ACM, $2467-2476$. Diperoleh 15 Mac, 2014 daripada http://hci.usask.ca/uploads/290-HBM_GamerType_Orji_CHI2013.pdf

Owens, J., Chaparro, B. S., \& Palmer, E. M. (2011) Text Advertising Blindness: The New Banner Blindness? Journal of usability studies, 6(3), 172-197.

Owen, D. J., Slep, A. M., \& Heyman, R. E. (2012). The Effect Of Praise, Positive Nonverbal Response, Reprimand, And Negative Nonverbal Response On Child Compliance: A Systematic Review. Clinical Child and Family Psychology Review, 15(4), 364-385.

Paay, J., Kjeldskov, J., Brinthaparan, U., Lichon, L., Rasmussen, S., Srikandaraja, N., Smith, W., Wadley, G., \& Ploderer, B. (2014). Quitty: Using Technology to Persuade Smokers to Quit. In Proc. Nordi CHI '14, ACM Press.

Pallant, J. (2011). SPSS Survival Manual: A Step By Step Guide To Data Analysis Using SPSS For Windows $4^{\text {th }}$ Edition. Australia: Allen \& Unwin.

Preece, J., Rogers, Y., \& Sharp, H. (2007). Interaction Design. (2 ${ }^{\text {nd }}$ edition). John Wiley \& Sons, Inc. New York.

Quinn, C. N. (2005). Engaging Learning: Designing e-Learning Simulation Games. Hoboken, NJ: Pfeiffer Essential Resources.

Read, J. C., \& MacFarlane, S. (2006). Using the Fun Toolkit and Other Survey Methods to Gather Opinions in Child Computer Interaction. In proceedings of Interaction Design and Children Conference (IDC), Tampere, Finland, 81-88.

Reeves, B., Cummings, J. J., Scarborough, J. K., \& Yeykelis, L. (2013). Increasing energy Efficiency With Entertainment Media: An Experimental And Field Test Of The Influence Of A Social Game On Performance Of Energy Behaviors. Environment and Behavior, 1-14. doi:0013916513506442.

Ronimus, M., Kujala, J., Tolvanen, A., \& Lyytinen, H. (2014). Children's Engagement During Digital Game-Based Learning Of Reading: The Effect Of Time, Rewards And Challenge. Computers and Education, 71, 237-246.

Ruggiero, D. (2014). The Effect Of A Persuasive Game On Attitude Towards The Homeless. Unpublished Thesis, Purdue University. Diperoleh 5 Mei, 2015 daripada http://www.fdg2014.org/papers/fdg2014_paper_26.pdf

Ruggiero, D. (2015). The Effect Of A Persuasive Social Impact Game On Affective Learning And Attitude. Computers in Human Behavior 45, $213-221$.

Scholastic. (2012). Kids and Family Reading Report, 4th Edition. Diperoleh 4 April, 2016 daripada http://mediaroom.scholastic.com/files/kfrr2013 wappendix.pdf.

Sussenbach, P., Niemeier, S., \& Glock, S. (2013). Effects of and Attention To Graphic Warning Labels On Cigarette Packages. Psychology and Health, 28, 11921206. doi:10.1080/08870446.2013.799161.

Tabachnick, B. G., \& Fidell, L. S. (2007). Using Multivariate Statistics (5 ${ }^{\text {th }}$ Ed.). Pearson Education: Boston.

Ventura, M., Shute, V., \& Zhao, W. (2013). The Relationship Between Video Game Use And A Performance-Based Measure Of Persistence. Computers \& Education, 60, 52-58. doi:10.1016/j.compedu.2012.07.003

Wan Abdul Manan, Wan Muda, Norazawati, A. K., \& Lee, Y.Y. (2012). Overweight and Obesity Among Malay Primary School Children in Kota Bharu, Kelantan: Parental Beliefs, Attitudes And Child Feeding Practices. Malays J Nutr, 18(1), http://nutriweb.org.my/publications/mjn0018_1/3WanManan\%20_327.pdf

Webb, M., \& Morancie, A. (2015). Food Safety Knowledge Of Foodservice Workers At A University Campus By Education Level, Experience, And Food Safety Training. Food Contr, 50, 259-64. doi: 10.1016/j.foodcont.2014.09.002

Yoganathan, D., \& Kajanan, S. (2014). Designing Fitness Apps Using Persuasive Technology A Text Mining Approach. In Proceedings of the 18th Pacific Asia Conference on Information Systems.

Zorbaz, S. D., Ulas, O., \& Kizildag, S. (2015). Relation Between Video Game Addiction And Inter Family Relationships On Primary School Students. Educational Sciences: Theory And Practice, 15 (2), 489-497.

Zuckerman, O., \& Gal-Oz, A. (2014). Deconstructing Gamification: Evaluating The Effectiveness Of Continuous Measurement, Virtual Rewards, And Social Comparison For Promoting Physical Activity. Personal and Ubiquitous Computing, 1 - $15 . \quad$ Diperoleh 8 April, 2016 daripada http://jotlt.indiana.edu/article/download/13455/19711 